\title{
(Neo)Platonic Thought in Saint John of the Cross and Stéphane Mallarmé
}

\section{El pensamiento neoplatónico en San Juan de la Cruz y Stéphane Mallarmé}

\section{Felix K. E. Schmelzer}

Universidad de los Andes

CHILE

fschmelzer@uandes.cl

[Hipogrifo, (issn: 2328-1308), 6.2, 2018, pp. 505-523]

Recibido: 03-08-2018 / Aceptado: 28-08-2018

DOI: http://dx.doi.org/10.13035/H.2018.06.02.38

Abstract. Conceived as the outline of a more detailed comparison, the present work aims to contribute to a better understanding of the similarities between Christian mysticism and modern lyrical poetry through a concrete comparison between Saint John of the Cross and Stéphane Mallarmé, focusing on four common (neo) Platonic ideas that determine their thought and poetry: first, both regard themselves as a mere medium through which an absolute spirit expresses itself; second, the deconstruction of language plays a central role in their work; third, both authors circle around the idea of a purification of the soul; last but not least, the idea which lies at the core of their work seems to be true self-recognition, that is, a self-contemplation of the individual soul that leads to a self-contemplation of the divine within ourselves.

Keywords. Saint John of the Cross; Stéphane Mallarmé; (Neo)Platonic Thought; Modern Poetry and Christian Mysticism; Religion and Literature Studies.

Resumen. Concebido como esbozo de un estudio más detallado, el presente trabajo pretende contribuir a una mejor comprensión de las similitudes entre la mística cristiana y la lírica moderna a través de una comparación entre San Juan de la Cruz y Stéphane Mallarmé. Se enfoca en cuatro ideas (neo)platónicas comunes que caracterizan su pensamiento y su poesía: primera, ambos se ven como un

1. This paper was completed thanks to the FONDECYT Research Project $N^{\circ} 11160382$, financed by CONICYT, Chile. 
mero medio a través del cual un espíritu absoluto se expresa a sí mismo; segunda, la deconstrucción del lenguaje juega un papel central en su obra; tercera, ambos autores giran en torno a la idea de una purificación del alma; por último, la idea fundamental de su obra es el verdadero autoconocimiento, es decir, una autocontemplación del alma individual que lleva a la autocontemplación de lo divino dentro de nosotros.

Palabras clave. San Juan de la Cruz; Stéphane Mallarmé; pensamiento (neo)platónico; poesía contemporánea y mística cristiana; estudios de religión y literatura.

There seem to exist certain similarities between mysticism, Christian mysticism in particular, and modern lyrical poetry². Henri Bremond (Prière et poésie, 1926) is among the first to reveal parallels between both traditions, and several studies have been published since $^{3}$. In one of the most recent works, Cirlot and Vega (2006) underline mysticism's role as a «founding phenomenon of Europe's spiritual identity» (9) whose traces can clearly be detected in $20^{\text {th }}$ century art and thought. Among the explanations of the-sometimes striking-affinities, the most important from my point of view is the Romantic ideal of art and poetry as religion, such as expressed by Novalis ${ }^{4}$ or Hölderlin ${ }^{5}$.This idea finds its theoretical background in Schleiermacher's famous definition of religion as «sense and taste for the infinite» ${ }^{6}$, words that imply an unfolding of the mystical in the realm of the poetical and esthetical. Suffering from an increasingly dominant scientific and positivist vision of the world, while simultaneously doubting the authenticity of an institutionalized religion, the Romantic poets regarded themselves as the last defenders of a sacred dimension of reality, a conviction still present at least until the first half of the $20^{\text {th }}$ century.

Within the aforementioned context, the present work aims to contribute to a better understanding of the similarities between Christian mysticism and modern lyrical poetry through a concrete comparison between a mystical and a modern poet. Even though one could perhaps argue that both Saint John of the Cross and Stéphane Mallarmé mark a highpoint within their tradition, bringing the poetic word as close to silence as they possibly can, their choice is, ultimately, derived via nothing more than intuition. Giving lectures on both authors at the same time, I could not help but feel remarkable structural parallels suggestive of a common ground.

\footnotetext{
2. In accordance with Friedrich (2006), I use the term modern lyrical poetry with regard to the postBaudelarian tradition.

3. Bremond describes both the mystical and the poetical experience as irrational, nonconceptual forms of cognition, resulting from a subject-object unification (pp. 220-221). To name a few other examples, Benjamin sees in Mallarmé the inventor of a negative theology of art (1961, p. 156), Wagner-Egelhaaf regards a mystical paradigm of dissimilar similarity («unähnliche Ähnlichkeit») as characteristic of Rilke and several other 20th century writers (1989, pp. 5-6), and Haas considers Fritz Mauthner and Paul Valéry to represent a particularly modern mysticism absent of God (2004, pp. 450-462).

4. See, for example, his famous essay Die Christenheit oder Europa (1799), which indicates an equating of the religious and the poetic sentiment.

5. Thinking of his poem Brot und Wein, which designates the poets as «sacred priests» (v. 123).

6. Über die Religion (quoted in Safranski, 2013, p. 141).
} 
Two years of research have led to the conclusion that, rather than by direct reception ${ }^{7}$, these parallels can be explained most satisfactorily by the presence in both authors' work of certain elements probably best classified as (Neo)Platonic. More concretely, I have detected four common ideas or motives that determine their thought and poetry: first, both regard their verses as a mere medium through which an absolute spirit -the Holy Spirit in Saint John, the «Spiritual Universe» in Mallarmé- expresses itself; second, the deconstruction of language plays a central role in their work, as shown by the motif of stutter; third, both authors circle around the idea of a purification of the soul which, at least in the case of Mallarmé, corresponds to a purification of language; last but not least, concomitant with the motif of mirroring, the idea which lies at the core of their work seems to be true self-recognition, that is, a self-contemplation of the individual soul that leads to a self-contemplation of the divine within ourselves. Let us take a closer look at how these ideas unfold themselves.

\section{A MOUTHPIECE OF THE HOLY SPIRIT, AN APTITUDE OF THE UNIVERSE}

Saint John of the Cross' treatises are curious texts because the author derives theological principles from an interpretation of his own poetry ${ }^{8}$, namely the three most famous poems, Cántico espíritual, Noche oscura, and Llama de amor viva. These texts try to explain, in hindsight, the lyrical verses within a scholastic, mainly Thomistic framework. This is an impossible task, as Saint John repeatedly points out in the prologue to Cántico espiritual (the treatise having the same title as the poem), because the true author of the poems is none other than the Holy Spirit. One could argue that this explanation is a rhetorical device to capture the interest of the reader, but the treatise was never meant to reach a wide readership. Moreover, it does not make his theological reflections more interesting, but instead the poems themselves, which had already been circulating. One might also speculate that the author is trying to protect his work and himself from the Inquisition, but the idea that God speaks through his verses directly seems more provocative than himself being the author. It seems likely that we are dealing with true (Christian) conviction:

sería ignorancia pensar que los dichos de amor en inteligencia mística, cuales son los de las presentes canciones, con alguna manera de palabras se puedan bien explicar; porque el Espíritu del Señor que ayuda nuestra flaqueza, como dice San Pablo (Rm. 8,26), morando en nosotros pide por nosotros con gemidos inefables lo que nosotros no podemos bien entender ni comprehender para lo manifestar. Porque ¿quién podrá escribir lo que las almas amorosas, donde él

7. It seems unlikely that the Frenchman knew the work of the Spanish mystic; I have not found any mention whatsoever in his writings, including his letters.

8. This aspect also caught the attention of Paul Valéry: «J'en viens maintenant à ce qui m'apparut la singularité de ces Traités: ils sont l'un et l'autre des commentaires de poèmes. [...] L'expression poétique sert donc ici de texte à interpreter, de programme à développer, aussi bien que d'illustration symbolique autant que musicale à l'expose de théologie mystique que j'ai effleuré plus haut. La mélodie sacrée s'accompagne d'un savant contrepoint qui tisse autour du chant tout un système de discipline intérieure» $(1957$, p. 447) 
mora, hace entender? Y ¿quién podrá manifestar con palabras lo que las hace sentir? Y ¿quién finalmente, lo que las hace desear? Cierto, nadie lo puede; cierto, ni ellas mismas por quien pasa lo pueden. Porque esta es la causa por que con figuras, comparaciones y semejanzas, antes rebosan algo de lo que sienten y de la abundancia del espíritu vierten secretos misterios, que con razones lo declaran.

Las cuales semejanzas, no leídas con la sencillez del espíritu de amor en inteligencia mística que ellas llevan, antes parecen distales ${ }^{9}$ que dichos puestos en razón, según es de ver en los divinos Cantares de Salomón y en otros libros de la Escritura divina, donde, no pudiendo el Espíritu Santo dar a entender la abundancia de su sentido por términos vulgares y usados, habla misterios en extrañas iguras y semejanzas (Prólogo, 1) ${ }^{10}$.

The passage implies the superiority of the poetic word over rational discourse ${ }^{11}$ when it comes to describing the otherness experienced throughout the unio mystica. In accordance with this, the Carmelite, in a subsequent passage, differentiates between mystical theology, that is, a knowledge gained through love, and scholastic theology, one gained through reason. As already mentioned, the quote further implies-and this is the main point to be emphasized here-that his verses originate from the Holy Spirit. In this manner, without saying so explicitly, the poet puts his work in a line with the Bible ${ }^{12}$, whose author, from a theological point of view, is the same Spirit, and, conceiving of himself as a mouthpiece of God, enters on a par with the ancient prophets.

Apart from the biblical context, Mallarmé's conviction concerning the origin of his verses is similar insofar as he also regards himself as a means of expression of the (an) absolute being. This can be deduced from several letters, especially those written during 1866 and 1867, a decisive period of a profound spiritual crisis ${ }^{13}$. Particularly important is one to his friend Cazalis, dated May 14, 1867: Mallarmé

9. «Dislates» (nonsenses).

10. If not marked otherwise, the quotes of Saint John of the Cross are taken from Obra completa, ed. López-Baralt and Pacho.

11. This is also the opinion of Hans Urs von Balthasar, who emphasizes the importance of the following quote with regard to the theological superiority of Saint John's verses over his prose comments: «Und Juan hat durchaus recht, wenn er den lehrhaften Teil seines Werkes als einen versagenden, abfallenden Kommentar zu seinen Gedichten hinstellt, in denen die eigentliche, von keiner Prosa einholbare Aussage erfolgt. Wenn man ihm die Richtigkeit dieser Selbstbeurteilung zutraut, dann ist er als Dichter mehr Kirchenlehrer denn als Prosaist» quoted in Teuber, 2003, p. 25). Parting from this idea, Teuber (2003, pp. 23-28) introduces the notion of Theopoetik in order to distinguish Saint John's poetical speech of God (according to Teuber, mainly a concealing) from a properly theological approach. In the context of a surmounting of rational knowledge in the poetry of Saint John of the Cross, see also López-Baralt (2015, particularly pp. 41-42).

12. Especially with the Song of Songs, the basic text of nuptial mysticism.

13. Bonnefoy (1995, p. 10) regards the months between late 1866 and early 1867 as particularly decisive. His description of this period of Mallarmé's work itself reads as mystical: «C'est dans ces quelques mois décisifs qu'il a «trouvé» le Néant, puis le Beau; qu'il a perçu que lorsque s'effondrent toutes les représentations que la conscience se forme demeure pourtant le mot, qui s'emplit alors, effacées les illusions de la connaissance, d'une évidence, d'une lumière, celles de la réalité sensible enfin retrouvée vierge, après tant de rapts par l'esprit». 
mentions a purity of thought he has reached through a vastly increased sensibility. Revealing mystical elements and ideas, he refers, in this context, to a descent into Darkness («Ténèbres», in capital letters) and Nothingness («Néant»), even to his own death. But it does not end here. All these tortures, it seems, were necessary for him in order to become a kind of obstetrician of the Spirit: "C'est t'apprendre que je suis maintenant impersonnel, et non plus Stéphane que tu as connu,-mais une aptitude qu'a l'Univers Spirituel à se voir et à se développer, à travers ce qui fut moi» (p. 343).

The idea of the immaterial universe regarding and unfolding itself-a point we return to later-is reminiscent of the philosophy of German Idealism, and Hegel's theory of art as a form of self-recognition of the Spirit in particular. In a broader context, it can be related to the self-contemplation of Intelligence, and of the three divine Hypostases (Soul, Intelligence, the One) in general, as conceived within Neoplatonic thought ${ }^{14}$. What I aim to show here is not Mallarmé's possible reception of this idea, but the idea in itself with regard to the inherent notion of the poet and his work. In comparison to Saint John of the Cross, the focus lies not so much on being a medium or mouthpiece of the Spirit but on the poet's mind becoming a room of unfolding and recognition for the Spirit, a slight but fascinating difference. Mallarmé does not develop the poetological implications of this idea in a concrete or systematic manner, but it seems that, to him, poetry itself is, at the same time, the emanation produced by the encounter between the poet's mind and the Spirit, and an impression-both metaphors are used in his work-of the Spirit within the poet's soul which, having transcended the empirical self, is receptive to the musical vibrations of the Universe.

The Romantic equation of religious and aesthetical experience -maybe, more precisely, poietic experience here-shines through. One could deduce that the Spirit becomes present in the poetic word and, moreover, even requires it in order to manifest itself. Understood in this sense, poetry is not conceived as a written account of a mystical union that has taken place outside the boundaries of language but lying itself at the core of such an experience- a particularly modern idea.

From a perspective of the history of ideas, both Saint John's and Mallarmé's reflections concerning the poet and the origin of his words can be regarded as variations of the Platonic notion of poetry as a form of enthousiasmos. According to Ion (534c-e), the poet is a «messenger of the Gods» (hermeneus tôn theôn) whose mind is possessed by a divine force (theia dynamis), deprived of his own reason and filled with a message that does not originate in himself15. In Saint John of the Cross, of course, this idea has to be regarded also in the context of the ancient Bib-

14. «Consistently with his general equation of greater unity with greater reality and power, Plotinus regards the greatest energy as produced by beings that do not squander their power in external activity, but keep it concentrated within themselves, a principle most fully exemplified by the tranquil self-contemplation of the divine Hypostases» (Wallis, 1995, p. 62). With regard to the influence on Plotinus', and also Proclus' ideas in the philosophy of German Idealism, and Hegel in particular, see Beierwaltes, 1972, pp. 144-187.

15. This idea is very popular in Romantic poetry in general; a good example, once again, is Hölderlin. 
lical Prophets. Mallarmé, on his part, modern and (unconsciously) Christian at the same time, suggests that the message lies within the process of its own manifestation or, as one could be tempted to say, incarnation.

\section{SUPREME STUTTER}

If I suppose the divine principle speaks through me, the question of its (in)effability becomes somewhat irrelevant. Nevertheless, this question lies at the core of the thinking of both Saint John of the Cross and Mallarmé. This apparent contradiction can be solved if we suppose that ineffability itself, in the end, is the subject of their poems. Following both authors' conviction of being transmitters of a universal being, this being would explain through them that it cannot be spoken or, more precisely, manifest its ineffable nucleus inside the boundaries of language. The biblical Jahwe-I am who I am-comes to mind. A reflection of Beierwaltes sheds light on what I mean. What is described here as a main characteristic of Neoplatonic philosophy and negative theology can also be applied to the poetry of Saint John and Mallarmé, with an important modification:

Philosophies of the absolute and theologies that are convinced of the incommensurability of their object are motivated by the question of the expressability of their highest object, which is nuclear for them. If it is evident within a common metaphysical horizon that the first principle or God cannot be grasped by categories or forms of thought coming from a logic adequate to the limited, finite, created, their whole terminological effort must be directed to express at least with reasons the inexpressibility of their object. Such philosophies and theologies are aligned, in accordance to their basic intention, with a clarification of the efficiency and functioning of language ${ }^{16}$.

The aforementioned modification is that poetry tries to go beyond philosophy and theology because it does not try to express the reasons for the highest principle's ineffability but, as already noted, this ineffability in itself. In other words, instead of obtaining a speculative understanding of the Absolute, poetry tries to create a room of unfolding. The decisive question is how this works linguistically. It is interesting that both Saint John and Mallarmé make use, in this context, of the motif of stutter, a metaphor that focuses on the syntactical and semantical deconstruction involved in the poetic process.

One of the most famous verses of the Cántico espiritual is «un no sé qué que quedan balbuciendo», imitating a stuttering voice in an onomatopoetic manner:

16. Beierwaltes, 1994, p. 52 («Philosophien des Absoluten und Theologien, die von der Inkommensurabilität ihres Gegenstandes überzeugt sind, werden durch die für sie zentrale Frage nach der Sagbarkeit ihres höchsten Gegenstandes bewegt. Wenn innerhalb eines gemeinsamen metaphysischen Horizontes als evident gelten kann, dass das erste Prinzip oder Gott nicht in Kategorien und Denkformen einer für Begrenztes, Endliches, Geschaffenes adäquaten Logik fassbar ist, dann muss ihre ganze begriffliche Anstrengung darauf gerichtet sein, zumindest die Un-Sagbarkeit ihres Gegenstandes mit Gründen sagbar zu machen. Derartige Philosophien und Theologien sind von ihrer Grundintention her auf eine Klärung von Leistung und Funktion der Sprache ausgerichtet [...]».). 


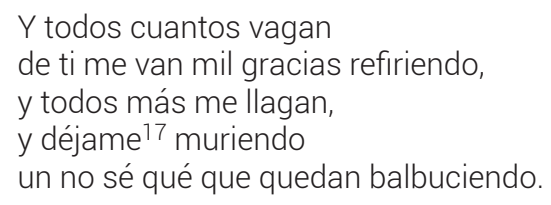

In the context of the strophe, as the poet himself indicates in his comment, the last verse can be read as an expression of the immensity of God the human soul perceives through the creatures. The totality of creatures, rational creatures in this case, communicates God-or we could also say God communicates himself through the creatures - in a manner that cannot be understood any more. According to the comment, it is precisely this lack of understanding that literally kills the soul so that it can be reborn in God. In this sense, not understanding-at the same time a very high understanding-is one of the highest gifts we can receive ${ }^{18}$.

In a more general context, the stutter can also be read with regard to the structure of the Cántico itself, whose lines, in decisive places, are incomprehensible from a logical point of view. Knowing that, the author openly admits that his verses are nonsenses («dislates») 19. This becomes especially obvious in strophes 13-1520:

$\begin{array}{ll}\text { LA ESPOSA } & \begin{array}{l}\text { ¡Apártalos, Amado, } \\ \text { que voy de vuelo! }\end{array} \\ & \\ \text { EL ESPOSO } & \text { - Vuélvete, paloma, } \\ & \text { que el ciervo vulnerado } \\ & \text { por el otero asoma } \\ & \text { al aire de tu vuelo, y fresco toma. } \\ & \\ & \text { Mi amado, las montañas, } \\ & \text { los valles solitarios nemorosos, } \\ & \text { las ínsulas extrañas, } \\ & \text { los ríos sonorosos, } \\ & \text { el silbo de los aires amorosos, } \\ & \text { la noche sosegada } \\ & \text { en par de los levantes de la aurora, } \\ & \text { la música callada, } \\ & \text { la soledad sonora, } \\ & \text { la cena que recrea y enamora. }\end{array}$

At this first highpoint of the poem, the bride (i.e., the human soul, within the code of nuptial mysticism ${ }^{21}$ ) has just conjured up the apparition of the bridegroom

17. As Ynduráin indicates (p. 250, note **), some manuscripts say «déjanme».

18. Cántico espíritual (comment) 7.1 y 7.9

19. Cántico espíritual (comment), Prólogo, 2.

20. Of the second version of the poem.

21. The kind of Christian mysticism reminiscent of the biblical Song of Songs and its interpretation by Bernard of Clairvaux, that is, expressing the unification of the human soul and God with the allegory of 
(God), looking at a crystalline fountain (strophe 12), and has now entered a state of ecstasy (the dove's flight) caused by His appearance. This appearance is too much to bear so she tells him to look away («Apártalos» refers to the bridegroom's eyes). This is precisely when the first unio seems to take place (strophe 13), a unification that reveals itself also at the metrical level, as the corresponding verse (the second in the quote) is spoken by both bride and bridegroom. Notable, likewise, is the accumulation of bilabials («voy», «vuelo», «vuélvete») that can be read as another onomatopoetic reference to stuttering.

The bridegroom then takes over the speech for a few verses and refers to himself in the third person, describing his own appearance as that of a wounded deer («ciervo vulnerado» ${ }^{22}$ ). She, at the same time, seems to pass into a calmed ecsta$\mathrm{sy}^{23}$ (strophes 14-15), perhaps resulting from the momentary union or maybe still experiencing that union itself as being completely (ful)filled by the other. Just here, the syntax is incomplete. Instead of a whole phrase, there is an accumulation of strange metaphors and paradoxical figures that recall a mystical visio, incoherent fragments not structured by any verb. With regard to the aforementioned idea, I think that these nonsenses, through a deconstruction or dissolution of rigid linguistic structures, create a poetic space that suggests the idea of a manifestation of the ineffable itself. After this enigmatic passage, the poem once again returns to more comprehensible speech.

The importance of the idea of stutter in the work of Saint John of the Cross also can be seen in the poem beginning with «Entreme donde no supe...» ${ }^{24}$, which circles around the apparent opposition knowing/not knowing, meaning, as indicated above, that the true knowledge revealed at the mystical union corresponds to a no-knowledge from the human perspective. Of interest is the way to this docta ignorantia as described in the poem: «Cuanto más alto se sube, tanto menos se entendía, que es la tenebrosa nube, que a la noche esclarecía» (vv. 32-35). Our knowledge and understanding dissipate precisely to the degree we get closer to God, who finally reveals Himself, in midst of the unknowing, in paradoxical manner as an illuminating cloud ${ }^{25}$. Transferred to the linguistic dimension, this means that our discursive speech dissolves itself increasingly into stutter or stumble the nearer we get to Him, as the second strophe indicates:

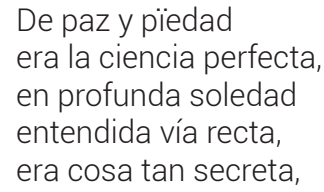


que me quedé balbuciendo,

toda ciencia trascendiendo.

In comparison to the Cántico and its famous verse, «un no sé qué que quedan balbuciendo», it is not God's communication through the creatures that is perceived as a stuttering, but the lyrical self itself that is stuttering. But this apparent difference may just be one of perspective, as one could say that in the latter case also, God expresses His ineffability, now through the resigned self of the poet: how far the self, at the precise moment of the unio, is still a 'self' is one of the central mysteries of Christian mysticism. The question of who is speaking thus seems rather irrelevant. What is relevant is that in the work of the poet, the motive of stuttering describes language's outlying district: a connecting link between human speech de-manifesting itself into the divine, and the divine manifesting itself into human language ${ }^{26}$, in an opposing movement perceived as an ongoing process.

In the work of Mallarmé, the idea of stutter appears at the end of one of his important poetological writings, Le mystère dans les lettres. Conceived as a sort of pamphlet against his critics ${ }^{27}$, this difficult and hermetic text consists of a series of aphoristic reflections that circle around the idea of obscurity or incomprehensibility as a necessary ground of existence that true poetry must reveal. This darker, or higher, dimension of reality, which, according to the Frenchman, worries the positivists among us, is circumscribed metaphorically as a barely noticeable profound mirroring, and also as a «beautiful cloud floating above the abyss of each thought». Moreover, it is related to the notion of a hidden signifier: «ll doit y avoir quelque chose d'occulte au fond de tous, je crois décidément à quelque chose d'abscons, signifiant fermé et caché, qui habite le commun» (p. 282). Reminiscent of the Platonic idea, this notion is one of the key elements of Mallarmé's thought, even though it is not developed in a systematic manner.

In the second part of Le mystère, Mallarmé focuses on the question of how true poetry, following the ideal of music, can reveal the obscure. Important in this context is the concept of interruptions: «Dites, comme si une clarté, à jet continu; ou qu'elle ne tire d'interruptions le caractère, momentané, de délivrance» (p. 284). The Absolute, now in terms of light (the paradoxical ensemble of light and darkness can

26. An idea somehow corresponding to T.S. Eliot's Dry Salvages: «But to apprehend / The point of intersection of the timeless / With time, is an occupation for the saint-» (p. 136). Moreover, I think that Thompson, in his famous study on Saint John, comes to a similar conclusion (2002, p. 369): «el lenguaje de su poesía representa el colapso de las certidumbres y dogmas humanos a medida que la humanidad es remodelada en las noches oscuras por la otredad divina. El lenguaje y los conceptos humanos no pueden contener a Dios; sin embargo, en el quebramiento de las normas de aquéllos hay un testimonio de la presencia de él».

27. Marchal explains in his edition of the text: «La cause prochaine de cet article inhabituellement polémique de Mallarmé était très vraisemblablement la publication, dans le número du 15 juillet de la même revue [La Revue blanche], d'un article de Marcel Proust, intitulé Contre l'obscurité. Cet article ne s'en prenait pas directement a Mallarmé -il attaquait les jeunes symbolistes-, mais il relançait la polémique sur I'obscurité poétique à une époque où Mallarmé était la cible mensuelle des articles d'Adolphe Retté dans La Plume. Mallarmé choisit donc de répondre une fois pour toutes à ses nombreux accusateurs» (p. 499). 
be viewed as another characteristic that relates both Saint John's and Mallarmé's work to the Neoplatonic tradition) is described with regard to our necessarily limited, that is, discontinuous, perception of it. A constant illumination would not be an illumination at all, for, in order to be perceived as such, it has to be interrupted. Mallarmé sees this principle fulfilled in (true) music: «Les déchirures suprêmes instrumentales, conséquence d'enroulements transitoires, éclatent plus véridiques, à même, en argumentation de lumière, qu'aucun raisonnement tenu jamais» ( $p$. 285). The interruptions, or as here, ruptures («déchirures»), correspond to momentary and fragmentary flashes of the divine, that to manifest itself, requires the destruction of a clearly perceptible structure or, perhaps more precisely, an opening of structure towards the Absolute. Interestingly, these ruptures are explained here as being consequences of transitory windings, a term which, in the poet's work, suggests a contact with the Absolute ${ }^{28}$.

Transferred to the realms of language, the concept of interruption or rupture finds its equivalent in the idea of stutter. Thus, it comes as no surprise that at the end of the text, ideal poetry is described as such:

Les abrupts, hauts jeux d'aile, se mireront, aussi: qui les mène, perçoit une extraordinaire appropriation de la structure, limpide, aux primitives foudres de la logique. Un balbutiement, que semble la phrase, ici refoulé dans l'emploi d'incidentes multiple, se compose et s'enlève en quelque équilibre supérieure, à balancement prévu d'inversions.

The quote has to be understood in the context of Mallarmé's poetics. Released from both semantic unambiguity and syntactic structure, the words mirror each other, and a total relation of everything to everything is created in the poem. This is achieved by Mallarmé's proclaimed technique of poetic suggestion ${ }^{29}$ and, an aspect the passage focusses on, conscient inversions that destroy the hierarchical order of the phrase. The result is a primordial stutter that composes itself within this dynamic linguistic interplay and, at the same time, elevates itself towards a higher equilibrium that is (probably) a unity of contradictions we can no longer perceive and that only the hidden signifier would be able to express.

As the subsequent passage of Le mystère indicates, the supreme stutter, that is, the free vibration of words within the poem, makes it possible to recognize momentarily a facet of what could be viewed again as a Platonic idea (the following words are reminiscent of the Allegory of the Cave): «Les mots, d'eux-mêmes, s'exaltent à mainte facette reconnue la plus rare ou valant pour l'esprit, centre de suspens vibratoire; qui les perçoit indépendamment de la suite ordinaire, projetés, en parois de

28. The description of the faun's encounter of the two tangled nymphs in the famous poem (L'Áprès-midi d'un faune) can also be interpreted in this sense. Even though the poem is highly erotic, according to Bonnefoy (1992, p. XXIII), it has a clearly spiritual background, in which the nymphs function as ciphers of the Absolute.

29. Expressed in his famous phrase against the realist poetics of the Parnassiens: «Nommer un objet, c'est supprimer les trois quarts de la jouissance du pöeme qui est faite de deviner peu à peu: le suggérer, voilà le rêve» (Sur l'évolution littéraire, p. 700). 
grotte, tant que dure leur mobilité ou principe» (pp. 286-287). The reader comes into play here: the suspension of semantic and syntactic order is something that also takes place in his mind, which is only capable of obtaining momentary freedom-in the sense of an absolute movement of words-and has to return to structure with necessity. But this moment seems sufficient to create a space of revelation.

From a poetological perspective, the difference in the way both authors apply the motif in question is not one of essence, but more one of focus. In the case of Saint John of the Cross, the focus is on the idea of ineffability, while in the case of Mallarmé, the revelation within the deconstruction of linguistic structure lies at the core. Neither meaning is self-exclusive. Even the apparent opposition between absolute stillness (strophes 14-15 of the Cántico) and absolute movement in the work of the two can be dissolved when we keep in mind that, for Mallarmé, both are essentially one and the same ${ }^{30}$.

\section{PURIFICATION}

The idea of purification is another key element in the work of both Saint John of the Cross and Mallarmé. According to both (Neo)Platonic and Christian mystical traditions, the human soul has to overcome its material boundaries in order to reunify with God (the One). From an intellectual standpoint, philosophy and theology are means of achieving that goal. For Mallarmé, a follower of Romanticism in that regard, poetry is the route. In any case, the idea of purification implies a certain disregard of matter, utter indeterminacy in Plotinian terms ${ }^{31}$, but, at the same time, leads to the conviction that matter (the physical world, the body, and, in the linguistic dimension, the poetic word) is also the place the return begins.

In the work of Saint John, the idea of purification corresponds to the first station of the mystical way, the via purgativa, the ultimate goal of which is to die to the world in order to be unified with God. This purification of the soul is closely related to the motif of the night. At the beginning of Subida del monte Carmelo ${ }^{32}$, the terms are even used as synonyms (I.1.1-3):

para que una alma llegue al estado de perfección, ordinariamente ha de pasar primero por dos maneras principales de noches, que los espirituales llaman purgaciones o purificaciones del alma, y aquí las llamamos noches, porque el alma, así en la una como en la otra, camina como de noche, a oscuras. La primera noche o purgación es de la parte sensitiva del alma [...]. Y la segunda es de la parte espiritual [...].

As the Carmelite explains in the continuation of the treatise, in accordance to Thomistic theology, the purification of the senses has to be understood as a morti-

30. This is indicated by a famous passage of Crise de vers which equates the total rhythm with the white poem: «Tout deviens suspens, disposition fragmentaire avec alternance et vis-à-vis, concourant au rythme total, lequel serait le poème tu, aux blancs» (p. 257).

31. Wallis, 1995, p. 48.

32. The first of his two large comments on the poem Noche oscura. 
fication of all the appetites in all things, whereas the purification of the intellect, the second night, means that the spirit or intellect («entendimiento») is freed from all images and concepts, including those of language. In this context, the basic ideas of negative theology become apparent, since, with God being the object of contemplation, all words and names become irrelevant because they originate in our imagination and intellect, which God transcends infinitely. Only after this twofold purification is the soul capable of finding the secret ladder of faith («escala de la fe»), hidden from both senses and intellect, that is, the temporary and the rational (II.1.1.). In this manner, it finally reaches a state of total nakedness («desnudez total») that corresponds to a complete inner darkness, the necessary precondition for contemplating God.

In both the Carmelite's theological and poetical writings, we find several images or motives complementary to the dark night and the idea of purification, mainly fire and the wound. The former refers to the purification of the spirit, that is, the second night. In their interplay, fire and night lead to a central paradox of Christian mysticism, the idea of a luminous obscurity or obscure illumination. God Himself, in the highest vision, manifests Himself as a ray of darkness ${ }^{33}$. Accordingly, in the famous poem, the dark night is, at the same time, very brilliant ${ }^{34}$. The purgative fire wounds the soul and finally causes its death or dissolution into nothingness, and it is precisely that death which marks the fulfilling of the unio mystica: «Y cuando viniere a quedar resuelto en nada, que será la suma humildad, quedará hecha la unión espiritual entre el alma y Dios, que es el mayor y más alto estado a que en esta vida se puede llegar» (Subida, II, 7.11).

The closest fit when describing this psychological mystery is probably Llama de amor viva, a poem that refers to the soul's death and rebirth as an ongoing process, in the present tense, in terms of an erotic act in which it is wounded over and over again by a flame. This is most strongly indicated in the first two strophes:

\author{
¡Oh llama de amor viva, \\ que tiernamente hieres \\ de mi alma en el más profundo centro! \\ Pues ya no eres esquiva, \\ acaba ya, si quieres; \\ ¡rompe la tela de este dulce encuentro! \\ ¡Oh cauterio suave! \\ ¡Oh regalada llaga! \\ ¡Oh mano blanda! ¡Oh toque delicado, \\ que a vida eterna sabe,
}

33. Noche oscura, II, 5.3. The paragraph relates directly to the work of Pseudo-Denys, who uses this me-

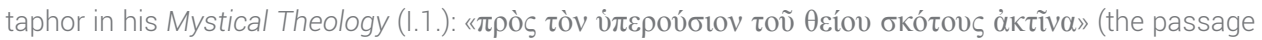
refers to the moment the mind enters «into the superessential radiance of the divine darkness»).

34. An excellent study of the darkness/light opposition in the work of the Carmelite from a semantic perspective is offered by Mancho Duque (1982, in particular pp. 49-60). 
y toda deuda paga!

Matando, muerte en vida la has trocado.

Whereas in the thought of Saint John of the Cross, the idea of purification is related primarily to the individual soul, in Mallarmé, it has to be understood primarily as a purification of language. Nevertheless, the two dimensions do not exclude each other; it is, once again, rather a question of focus ${ }^{35}$. Negative theology, a determinant component of the Carmelite's work and its inherent poetics, is basically a theory of language-purification with regard to the (im)possibilities of expressing God. Mallarmé, on the other hand, in a point often overlooked, insists in both his poetological essays and letters on the desired effect his poetry shall cause in the reader, that is, precisely, a purification of the soul.

A key element of Mallarmé's notion of purification, proving that the purification of the poetic word and the desired purification of the soul cannot be neatly separated in his work, is the relation thing/object («objet»)-state of soul («état de l'âme»). As Bonnefoy has pointed out, Mallarmé is the last medieval poet in the sense that he is aware of a profound correspondence between the objects of the material world and their spiritual ground ${ }^{36}$, an awareness gradually lost throughout the Modern Age. As a consequence, the human soul is increasingly saturated in the material dimension. Le mystère and other poetological texts indicate that the French poet perceives this dilemma to have come to a highpoint at his time. In the late $19^{\text {th }}$ century, objects are only perceived from a positivist viewpoint, which is why also the words designating them have become encrusted with regard to their spiritual nucleus. Trivial literature and the contemporary popular press, against which Mallarmé defends poetry decisively, are a natural outcome of this decay. From this perspective, Mallarmé's poetics are a consequent attempt to purify the soul by de-crusting the poetic word and freeing it from its positivist ballast. The main idea behind this is: the less concrete the object becomes in the poem, the less the soul is condemned to the material world ${ }^{37}$.

How this idea of a poetical (and psychological) purification process translates into a poem can be shown exemplarily in Sainte ${ }^{38}$ :

\author{
A la fenêtre recélant \\ le santal vieux qui se dédore \\ de sa viole étincelant \\ jadis avec flûte ou mandore,
}

35. In his pioneering work when it comes to comparing both authors, Milner (1970) simplifies strongly by restricting the notion of purification to the empirical dimension in Saint John and to the linguistic dimension in Mallarmé

36. Bonnefoy, 1992, pp. VII-XVI. Bonnefoy sees an interesting relation in particular between Mallarmé's medieval thought and his radical modernism: «Le jeune homme inquiet et fervent qui avait été le dernier médiéval parmi les poètes de son époque est devenu brusquement le plus radical des modernes» (pp. XV-XVI).

37. Even though not formulated in a direct manner, this idea is inherent to Mallermé's poetics

38. All of Mallarmés poems quoted from Poésies, ed. Marchal (1992). 
est la Sainte pâle, étalant le livre vieux qui se déplie du Magnificat ruisselant jadis selon vêpre et complie:

A ce vitrage d'ostensoir que frôle une harpe par l'Ange formée avec son vol du soir pour la délicate phalange

du doigt, que, sans le vieux santal ni le vieux livre, elle balance sur le plumage instrumental, Musicienne du silence.

The poem is marked by an isotopy of both the sacred and of music. Like basically all of Mallarmé's lyrical texts, it circles around poetry itself, whose ideal form is usually described as music. Understood in this context, the verses suggest that true poetry, and that is also true religion in this case, is a music of silence ${ }^{39}$.

As Friedrich (1957) has shown masterfully, the poetic procedure that determines this little text can be described as de-objectivizing ${ }^{40}$. From the first verse on, we get to know that the objects referred to are hidden from us by a window. Moreover, they are brought into temporal absence by the repetition of the adverb once («jadis») and related to the idea of material decay by the repetitive use of old («vieuX») and the notion of de-gilding («dédore»). The idea behind this is that the dissolution of the material causes the purely spiritual to come into being in the poem, insinuated by the very soft touch of the angel's wing (vv. 10-11). In other words, only a language purified from its concrete material significance can become a room of emanation for the spiritual idea. Such a (Neo)Platonic lecture is in accordance to a famous remark of Crise de vers that, as it seems, is put into praxis in the poem: «À quoi bon la merveille de transposer un fait de nature en sa presque disparation vibratoire selon le jeu de la parole, cependant; si ce n'est pour qu'en émane, sans la gêne d'un proche ou concret rappel, la notion pure» (259). The birth of the idea («notion pure») in the poem corresponds in Mallarmé's thought to the assumption that the reader's soul recognizes itself in the process of emanation in the poem, that is, becomes aware of its spiritual and musical origin ${ }^{41}$.

39. Accordingly, Bénichou (1995, p. 132) characterizes the poem as follows: «il [Mallarmé] y exalte, dans cette sainte [...], jouant sur l'aile d'un ange, une silencieuse musique, l'idée limite de sa propre poétique: l'exténuation du chant jusqu'au silence, figure de celle de l'être dans l'idéalisme mallarméen».

40. Friedrich, 2006, pp. 97-100.

41. Several formulations suggest that Mallarmé's musical concept of the soul is essentially pythagorean: «tout âme est un nœud rhytmique» (La musique et les lettres, p. 371); «tout âme est une mélodie, qu'il s'agit de renouver» (Crise de vers, p. 252)... 


\section{MIRRORS}

The ultimate goal of the purification process, as indicated, is true self-recognition, an idea related to the motif of mirroring in both authors' work. In the case of Mallarmé (to turn around the analytical order for once), this idea is not necessarily connotated in a positive manner but is accompanied in his letters by a sentiment of horror. In accordance with that, the purification of the soul is also perceived less through the Christian perspective of divine grace and salvation, but as a destruction of the soul, descent into the abyss of nothingness, or disease. Marking the end of this way, self-recognition is conceived in his work as recognition of a transcendent entity within ourselves, an entity which, to the degree the individual ceases, contemplates itself in and through the human soul. It is highly significant that this mystical thought appears repeatedly in a decisive period of Mallarmé's work, 18661868, in both his letters and poems.

I would like to refer once again to that particularly important letter to Cazalis (May 14, 1867), the central passage of which begins: «ma Pensée s'est pensée, et est arrive à une Conception Pure». In the following lines, Mallarmé describes the terrors and tortures he had to suffer to achieve that auto-contemplative state of mind as a terrible fight that forced him to look nothingness in the eye. Curiously, what finally liberated him from the darkness he had fallen into was a look into the mirror, in which he no longer recognized himself, but the «Spiritual Universe» (part of the following quote has already been mentioned above):

Ténèbres, je tombai, victorieux, éperdument et infiniment-jusqu'à ce qu'enfin je me sois revu un jour devant ma glace de Venise, tel que je m'étais oublié plusieurs mois auparavant. J'avoue, du reste, mais à toi seul, que j'ai encore besoin, tant ont été grandes les avaries [sic] de mon triomphe, de me regarder dans cette glace pour penser, et que si elle n'était pas devant la table où je t'écris cette lettre, je reviendrai le Néant ${ }^{42}$. C'est t'apprendre que je suis maintenant impersonnel, et non plus Stéphane que tu as connu, -mais une aptitude qu'a I'Univers Spirituel à se voir et à se développer, à travers ce qui fut moi.

The mirror is also a key motif of Hérodiade, the famous dramatic poem of the early period, the first version of which was finished in 1866. As the poet himself indicates, Hérodiade embodies the ideal beauty which, for the first time in history, obtains self-consciousness ${ }^{43}$. This is reflected in the first scene, where Hérodiade asks her nurse to hold the mirror for her: «Assez, tiens devant moi ce miroir. Ô miroir! / [...] Je m'apparus en toi comme un ombre lointaine. / Mais, horreur! des soirs, dans ton sévère fontaine, / J'ai de mon rêve épars connu la nudité!» (vv. 43-51). A possible lecture: the Absolute, in the poem connoted as a cold, unapproachable beauty (a rather negative notion typical of Mallarmé's early work), contemplates itself and its own nakedness through the poet (the nurse) and his work (the mirror).

42. Correction in the manuscript: «je retomberais dans mon Néant».

43. Mallarmé describes this particular idea, comparing his Hérodiade to the Venus de Milo and the Mona Lisa, in a letter to Eugène Lefébure (27 May, 1867; Correspondances, pp. 346-355). 
The mirror further appears in two of Mallarmé's most difficult sonnets, which also can be read with regard to a self-reflection of the Absolute being in and through the poetic language: the Sonnet en $-x$ and Éventail. Both texts burst the reader's understanding in the end, and they probably have to because the self-recognition of Spirit, from my point of view, is the mystery at the core of Mallarmé's poetry. Slightly less enigmatically, one could state that the intellect, at the boundaries of silence, sees itself reflected in the process of his linguistic (de-)manifestation. Friedrich was the first to recognize that: «Denn solche Lyrik hat nichts mehr zu tun mit Gefühlspoesie, Erlebnispoesie, Erscheinungspoesie. Fremdartig, aber in still zwingenden Tönen spricht sie aus einem körperlosen, einsamen Innenraum, wo der Geist, frei von den Schatten des Wirklichen, sich selber zusieht» (100).

In the work of Saint John of the Cross, the motif of mirroring emerges with less frequency, but it is meaningful that the (or a) highpoint of the Cántico espiritual is introduced by a suggested reflection of the lyrical self, the bride, in a crystalline fountain (strophes 11-12):

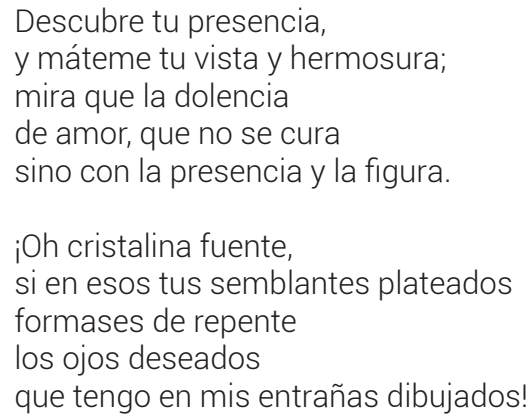

In this case also, the mirroring can be read in the sense of true self-recognition, the recognition of a transcendent source, God, who appears for the first time in the poem in the following strophe (13), within ourselves.

The metaphor of the fountain seems particularly adequate not only for suggesting the idea of purity, but also for insinuating a not yet clear, fuzzy, and moving image. It is the gaze of God whose essence cannot be supported, even though He seems to be continually looking at us, as the poet indicates in the comment (12.5). At the same time, and this is what makes the passage enigmatic, the «eyes drawn in my entrails» seem to be the eyes of the bride's own soul44 (this becomes clear in the earlier version of the poem, which does not include the first of the quoted strophes), that is, purely spiritual eyes, the only ones capable of contemplating Him. This ambiguity, something only poetry can deliver, could be explained by the suspension of identities at the moment of the unio. Once again, the corresponding comment is helpful: «cuando hay unión de amor, [...] es verdad decir que el Amado vive en el amante, y el amante en el Amado, y tal manera de semejanza hace el amor en la 
transformación de los amados, que se puede decir que cada uno es el otro y que entrambos son uno» (12.7). One of the most concise expressions of this nuclear mystical paradox can be found in Meister Eckhart: «Daz ouge, dâ inne ich got sihe, daz ist daz selbe ouge, dâ inne mich got sihet; mîn ouge und gotes ouge daz ist éin ouge und éin gesiht und éin bekennen und éin minnen» ${ }^{45}$.

\section{SOME CONCLUSIONS}

Even though the present work should be regarded as a draft of a more detailed analysis, it has become clear that there are similarities in the work of Saint John of the Cross and Stéphane Mallarmé which show themselves in the four common ideas or motives briefly analyzed. As already stated, I believe it is appropriate to characterize these similarities as structural parallels of thought that refer to a common (Neo)Platonic substratum, unfolding itself in Christian mysticism (the work of Pseudo-Denys is basically an application of Plotinus' ideas) as well as $19^{\text {th }}$ century poetry. Concerning the latter, the Platonic idea of poetry as a form of enthousiasmos is decisive, but also the affinity of the philosophy of German idealism for Neoplatonic ideas, particularly concerning the self-contemplation and recognition of the Spirit ${ }^{46}$. The question of the way in which Mallarmé came in contact with these ideas (in the case of Saint John, a direct influence of Pseudo-Denys is obvious) does not seem clear to me. He knew Hegel, but it seems uncertain to what degree. But maybe this question is not the most interesting one.

A detailed comparison should focus more decisively on the main differences in the thought of the two, although it seems always difficult to draw a sharp frontier. Mallarmé's God, for example, is not a personal God, even though the erotic ciphering of the Absolute as feminine in his work, such as the nymphs evading the faun in the famous poem ${ }^{47}$, could be read as a reversed nuptial mysticism. But also, if we accept the possibility of this lecture, the idea of a unio in his work is, of course, far more ambiguous than in Saint John of the Cross. A direct contact with the Spirit is not necessarily achievable any longer; and if it is, then in the (modern) sense of a purely intellectual and fragmentary contemplation within a process of deconstruction of language and identity...

\section{BIBLIOGRAPHY}

Beierwaltes, Werner, Platonismus und Idealismus, Frankfurt am Main, Klostermann, 1972.

Beierwaltes, Werner, Eriugena, Frankfurt am Main, Klostermann, 1994.

45. «The eye with which [or in which] I see God is the same eye with which God sees me; my eye and the eye of God, that is one eye, and one face, and one confession and one love» (quoted in Haas, 2007, p. 145). 46. An illuminating chapter on the influence of Neoplatonism on German idealism can be found in Beierwaltes, 1972, pp. 83-187.

47. L'Ápres-midi d'un faune. The faun would be the poet. 
Bénichou, Paul, Selon Mallarmé, Paris, Gallimard, 1995.

Benjamin, Walter, «Das Kunstwerk im Zeitalter seiner technischen Reproduzierbarkeit», in Illuminationen, Frankfurt am Main, Suhrkamp, 1961, pp. 148-184.

Bonnefoy, Yves, «Préface», in Stéphane Mallarmé, Poésies, ed. Bertrand Marchal, Paris, Gallimard, 1992, pp. VII-XXXVI.

Bonnefoy, Yves, «Préface», in Stéphane Mallarmé, Correspondance, ed. Bertrand Marchal, Paris, Gallimard, 1995, pp. 7-29.

Bremond, Henri, Prière et poésie, Paris, Grasset, 1926.

Cirlot, Victoria and Amador Vega (eds.), Mística y creación en el siglo XX, Barcelona, Herder, 2006.

Eliot, T.S., The Complete Poems and Plays, New York, Harcourt, 1952.

Friedrich, Hugo, Die Struktur der modernen Lyrik, Reinbek bei Hamburg, Rowohlt, 2006 [1956].

Haas, Alois M., Mystik im Kontext, München, Fink, 2004.

Haas, Alois M., «Überlegungen zum mystischen Paradox», in Mystik als Aussage, Frankfurt am Main, Insel, 2007, pp. 149-171.

Hölderlin, «Brot und Wein», in Sämtliche Gedichte, ed. Jochen Schmidt, Frankfurt am Main, Deutscher Klassiker Verlag, 2005, pp. 285-291.

Juan de la Cruz (John of the Cross), Poesía, ed. Domingo Ynduráin, Madrid, Cátedra, 2015 [1983].

Juan de la Cruz (John of the Cross), Obra completa, ed. Luce López-Baralt y Eulogio Pacho, Madrid, Alianza, 2015, 2 vols.

López-Baralt, Luce, «Prólogo», in San Juan de la Cruz, Obras completas, ed. Luce López-Baralt and Eulogio Pacho, Madrid, Alianza, 2015, vol. 1, pp. 9-48.

Mallarmé, Stéphane, Correspondance, ed. Bertrand Marchal, Paris, Gallimard, 1995.

Mallarmé, Stéphane, «Crise de vers», in Igitur. Divagations. Un coup de dés, ed. Bertrand Marchal, Paris, Gallimard, 2003, pp. 247-260.

Mallarmé, Stéphane, «La musique et les lettres», in Igitur. Divagations. Un coup de dés, ed. Bertrand Marchal, Paris, Gallimard, 2003, pp. 358-389.

Mallarmé, Stéphane, «Le mystère dans les lettres», in Igitur. Divagations. Un coup de dés, ed. Bertrand Marchal, Paris, Gallimard, 2003, pp. 281-288.

Mallarmé, Stéphane, Poésies, ed. Bertrand Marchal, Paris, Gallimard, 1992.

Mallarmé, Stéphane, «Sur l'évolution littéraire», in E Euvres complètes, ed. Bertrand Marchal, Paris, Gallimard, 2003, II, pp. 697-702.

Mancho Duque, María Jesús, El símbolo de la noche en San Juan de la Cruz, Salamanca, Ediciones Universidad de Salamanca, 1982. 
Milner, Max, «Ascétisme poétique et ascétisme mystique: Mallarmé et saint Jean de la Croix», in Actualité de Jean de la Croix, ed. Lucien-Marie and Jaques-Marie Petit, Paris, Desclée de Brouwer, 1970, pp. 219-233.

Novalis, «Die Christenheit oder Europa», in Werke, ed. Gerhard Schulz, München, Beck, 2013, pp. 499-518.

Plato, Ion, in Werke, I, transl. Friedrich Schleiermacher, ed. Heinz Hofmann, Darmstadt, WBG, 2016.

Plato, Politeia, in Werke, IV, transl. Friedrich Schleiermacher, ed. Heinz Hofmann, Darmstadt, WBG, 2016.

Pseudo-Denys (Dionysius the Areopagite), The Divine Names and Mystical Theology, trans. Clarence E. Rolt, London, Society for the Propagation of Christian Knowledge, 1920.

Safranski, Rüdiger, Romantik. Eine deutsche Affäre, Frankfurt am Main, Fischer, 2013.

Teuber, Bernhard, Sacrificium litterae. Allegorische Rede und mystische Erfahrung in der Dichtung des heiligen Johannes vom Kreuz, München, Fink, 2003.

Thompson, Colin P., Canciones en la noche. Estudio sobre san Juan de la Cruz, Madrid, Trotta, 2002.

Valéry, Paul, «Cantiques spirituels», in Fuvres, I, ed. Jean Hytier, Paris, Gallimard, 1957, pp. 445-457.

Wagner-Egelhaaf, Martina, Mystik der Moderne. Die visionäre Ästhetik der deutschen Literatur im 20. Jahrhundert, Stuttgart, Universität Tübingen, 1989.

Wallis, Richard T., Neoplatonism, London, Bristol Classical Press, 1995 [1972]. 